\title{
Environmental Factors Related to Leptospirosis in Indonesia: A Systematic Review
}

\author{
Arinil Haq ${ }^{1}$, Sevrima Anggraini², Yeffi Masnarivan ${ }^{3}$ \\ \{ arinilhaq@ph.unand.ac.id ${ }^{1}$, sevrimaanggraini@gmail.com², \\ yeffimasnarivan@ph.unand.ac.id ${ }^{3}$ \} \\ Faculty of Public Health, Andalas University, Padang, Indonesia ${ }^{1,3}$, \\ Faculty of Public Health, Universitas Indonesia, Depok, Indonesia ${ }^{2}$
}

\begin{abstract}
Leptospirosis is a zoonosis of worldwide distribution, especially subtropical or tropical countries, including Indonesia. Therefore, it is important to know what environmental factors related to leptospirosis in Indonesia. This research is a systematic review of 9 eligible research journals that published in 2005-2019 in Indonesia. Journals are obtained from Science Direct, PubMed, and Garuda databases. A total of 4 studies examining the relationship between the existence of rats with leptospirosis cases, found that there was a statistically significant relationship. A total of 3 studies found that there was a statistically significant relationship between a pool of water with leptospirosis cases. Meanwhile, 2 out of 4 studies found that there was a significant relationship between poor sewer conditions and poor garbage conditions with leptospirosis cases. In conclusion, most studies found that the existence of rats, a pool of water, poor sewer conditions, and poor garbage conditions are significantly related to leptospirosis cases in Indonesia.
\end{abstract}

Keywords: Leptospirosis, environmental, rats

\section{Introduction}

Leptospirosis is a zoonotic disease caused by infection of leptospira interrogates of all serotypes. Leptospirosis is also known as flood fever because it often causes outbreaks during floods. According to the International Leptospirosis Society (ILS), Indonesia is a country with a high incidence of leptospirosis and is ranked third in the world for mortality [1].

Weil first discovered this disease in 1886, but in 1915 Inada found the cause, namely Spirochaeta of the genus leptospira [1,2]. Among the genus leptospira, only interrogative species are pathogenic to animals and humans. There are at least 180 serotypes and 18 serogroups. One type of serotype can cause a different clinical picture; on the contrary, a clinical picture, for example, aseptic meningitis, can be caused by various serotypes [2]. Leptospirosis has broad and varied clinical manifestations. In mild leptospirosis, symptoms such as influenza with headache and myalgia can occur. Severe leptospirosis is characterized by jaundice, kidney disorders, and bleeding, known as Weil's syndrome [1].

This disease is a public health problem throughout the world, especially countries with tropical and sub-tropical countries that have high rainfall. This, coupled with poor environmental conditions, is good land for the survival of pathogenic bacteria so that it allows the environment to be a suitable place to live and breed Leptospira bacteria [3]. 
Cases of leptospirosis in Indonesia always increase every year, wherein 2016, there were 830 cases and an increase in 2017 of 908 cases. It also followed by an increase in the case fatality rate (CFR) of $7.35 \%$ in 2016 , increasing to $14.98 \%$ in 2017 , and again an increase in 2018 of $16.65 \%$. In Indonesia alone, seven provinces reported cases of leptospirosis in 2018, namely DKI Jakarta, West Java, Central Java, DI Yogyakarta, East Java, Banten, and Maluku [4].

Transmission of leptospirosis occurs due to poor environmental conditions in residential areas. The poor environment can increase food availability, shelter, nest, and breed mice as a reservoir of leptospirosis. Besides, a bad environment can cause flooding, which can increase the risk of leptospirosis [5].

$\mathrm{Tt}$ is important to know what environmental factors are associated with leptospirosis. Besides, there are many studies on leptospirosis in Indonesia.

\section{Method}

\subsection{Search strategy}

We conducted a systematic review of some literature that examines the relationship between environmental factors and leptospirosis occurrence in Indonesia. Preferred Reporting Items for Systematic Reviews and Meta-Analyses statements (PRISMA) were used to report the study selection process included in this research and the result of this research. Three electronic databases were searched: ScienceDirect, PubMed, and Garuda.

\subsection{Inclusion criteria}

We defined search terms, which were in English and Indonesian, that is environment [AND] leptospirosis [AND] Indonesia, and lingkungan [DAN] leptospirosis. We included only journal articles published from 2005 to 2019. We included studies on human leptospirosis, journal articles only, and published in English and Indonesia language. We limit the study to only those using cross-sectional and case-control study design. 


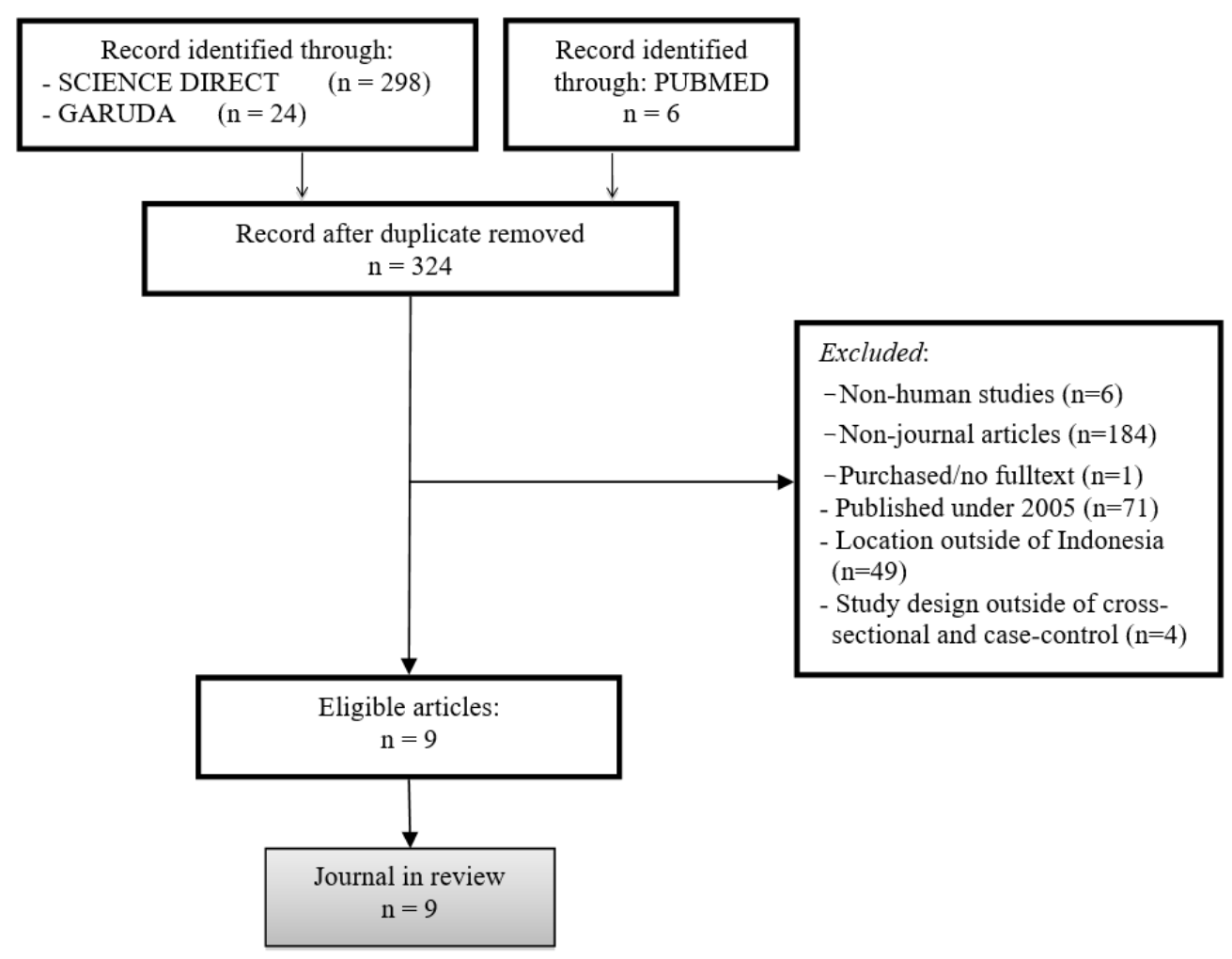

Fig. 1 Preferred Reporting Items for Systematic Reviews and Meta-Analysis (PRISMA) 2009 Flow Diagram Showing Study Selection Process

\section{Result}

\subsection{Study selection}

We identified 328 studies that were obtained through online literature searches. After removed duplicate articles, 324 articles were obtained. The next step is articles screening with inclusion criteria, and then we got nine articles. A total of 315 articles were excluded due to non-human studies, non-journal articles, purchased / not available full text, published under 2005, a location outside of Indonesia, study design outside of cross-sectional and case-control.

\subsection{Study characteristics}

Two studies were published in 2007 [6,3], two studies were published in 2010 [7,8], one study was published in 2012 [9], one study was published in 2014 [10], one study was published in 2015 [11], and two studies were published in 2016 [12,13].

Three out of nine studies used a cross-sectional study design, and six out of nine studies used a case-control study design. Environmental variables that studied in these studies were the 
existence of shrubs, the existence of rats, a pool of water, poor sewer condition, and poor garbage condition, walled not wall, the existence of clean water facilities, house cleanliness, no ceilings, having pets, and condition of rat-proofing. A total of 901 participants were involved in these studies.

\subsection{Environmental factors}

Five studies found that the existence of rats has a significant relationship with leptospirosis $[6,9,10,12,13]$. The results of three studies found that there is a relationship between a pool of water with leptospirosis $[9,10,13]$. Two out of five studies found that poor sewer condition has a significant relationship with leptospirosis $[10,13]$. Two out of four studies that examined the relationship between garbage condition and leptospirosis, found that there is a relationship between them $[10,11]$.

\section{Discussion}

\subsection{Main findings}

Leptospirosis is a disease carried by animals infected by leptospira bacteria that have an impact on morbidity and death in humans [14]. Leptospirosis cases generally occur because of zoonotic pathogens from rats; the presence of rats is the most potent factor for this disease. Leptospirosis infections usually occur because of direct contact with infected animals with humans [7]. Direct transmission is caused by direct contact between urine/blood/ organs of animals infected with leptospira bacteria through wounds on the skin, conjunctiva, mucous membranes of the mouth, or nose. This transmission often occurs because there is a pool of water and soil that has been contaminated by animal urine containing leptospira [14,15]. Meanwhile, indirect transmission occurs due to contact between the skin that is not wounded with water contaminated with mouse urine in a time long time [16].

Prevention of leptospira infection in humans can be done by reducing the rat population as pathogenic animals carrying leptospira bacteria. The reduction of the rat population is made by making permanent changes to the environment in which the mice breed [16]. Almost all research in this study found that there was a significant relationship between the incidence of leptospirosis with the presence of mice. Moreover, several studies also found a significant relationship between standing water, poor drainage conditions, and reduced waste conditions with leptospirosis cases.

One of the most famous cases of leptospirosis is standing water and sewerage conditions. Open sewers and public sewage are also factors that influence the presence of vectors and the incidence of leptospirosis. Poor, open sewage channels provide an entrance for infected mice to contaminate waterways [17]. This is a potential risk for leptospirosis because rats are the main reservoir for leptospirosis. The presence of rats in the home environment must be an essential concern to avoid transmission of this disease [16]. Environmental conditions that do not meet health requirements are ideal places for rats to search for food and breed.

For this reason, it is necessary to maintain a clean environment and house as well as to keep water storage and drainage closed adequately. In addition to poor water sanitation, the presence of standing water around the environment and home is also a factor that causes leptospirosis. Many puddles occur during the rainy season. Stagnant water after rain and flooding can be mixed with contaminated feces and urine of rats [8]. 
Research conducted by Siti Maisyaroh in 2014 in the Leptospirosis endemic area of Pati, Central Java Province, found that there was a relationship between standing water and leptospirosis. Based on the results of these studies found many events of leptospirosis during the high rainfall season, which is around February 2014. In addition to standing water, sewer conditions are also a factor influencing the incidence of leptospirosis in the study [10]. In line with research conducted by Ghinna Maniiah in 2016 and Niky Ria in 2012 found a significant relationship between the condition of a pool of water with the incidence of leptospirosis $[9,13]$. Not in line with research conducted by Nurulia in 2016 that found no relationship between sewer conditions and puddles on the incidence of leptospirosis $(p>0.05)$ [12].

Poor waste management is also a trigger factor for leptospirosis cases. Research conducted by Tri Ramadhani in 2015 found that poor waste management became a place frequented by rats. Household hygiene and waste management, both reliable and easy to rot and rubbish are not easy to rot [11]. The rest of the food (junk) is a source of rat food. So that poor waste management both inside and outside the home can increase contact between rats and humans. Arrangement of home furniture is also related to house cleanliness because houses that are not neatly arranged tend to be found much trash and can be a hiding place for mice [18]. The presence of mice around the house is determined by two main factors, namely, the availability of feed and nesting sites [11]. This is confirmed the research conducted by Mari Okatini et al. in 2007, which found a significant relationship between poor home conditions and the incidence of leptospirosis. The poor condition of the house is marked by a house that is dirty, damp, congested, and so on. Dirty houses are caused due to poor waste management [3].

\subsection{Limitations}

Our systematic review found that research on leptospirosis has been widely practiced, but partly in the form of gray literature excluded in this study. The unavailability of complete data in the full paper makes us unable to display result data in the form of tables or graphs. The results of these studies are inconsistent, making it a little difficult to describe, but the most dominant or often the most dominant results are found.

\section{Conclusion}

Based on this systematic review, most studies found that the environmental factors, namely the existence of rats, a pool of water, poor sewer conditions, and poor garbage conditions, are significantly related to leptospirosis cases in Indonesia. It is recommended to maintain environmental hygiene and health, and also good living habits to prevent transmission of leptospirosis.

\section{References}

[1] Terpstra W, Adler B, Ananyina B, Andre-Fontaine G, Ansdell V, Ashford D. Human Leptospirosis: Guidance for Diagnosis, Surveillance and Control 2003.

[2] Soedarma S, Garna H, Hadinegoro S, Satara I. Textbooks on Infection and Tropical Pediatrics (2nd ed) 2008

[3] Okatini M, Purwana R, Djaja IM. Hubungan Faktor Lingkungan dan Karakteristik Individu terhadap Kejadian Penyakit Leptospirosis di Jakarta, 2003-2005. Makara Kesehat 2007;11:17-24. 
[4] Kementerian Kesehatan RI. Profil Kesehatan Indonesia Tahun 20182018.

[5] Riyaningsih T, Yunianto B. Environmental Risk Factors for Leptospirosis in Central Java (Case Study in Semarang City, Demak Regency, and Pati). J Kesehat Lingkung Indones 2010.

[6] Farida DH, Ristiyanto, Yuliadi B, Sukarno, Muhidin. Distribusi dan Faktor Resiko Lingkungan Penularan Leptospirosis di Kabupaten Demak, Jawa Tengah. J Vektora 2006;II:126-39.

[7] Ikawati B, Nurjazuli. Analisis Karakteristik Lingkungan Pada Kejadian Leptospirosis di Kabupaten Demak Jawa Tengah Tahun 2009. Media Kesehat Masy Indones 2010;9:33-40.

[8] Muhidin, Ristiyanto. Survei Demografi dan Kondisi Lingkungan Rumah di Daerah Kasus Leptospirosis di Desa Sumbersari Kecamatan Moyudan Kabupaten Sleman D.I. Yogyakarta Tahun 2010. J Vektora 2010;IV:53-60.

[9] Diananty NR. Hubungan Antara Faktor Lingkungan Fisik Rumah dan Keberadaan Tikus dengan Kejadian Leptospirosis di Kota Semarang. J Kesehat Masy 2012;1:1018-28.

[10] Maisyaroh S, Pertiwi B, Setiani O. Faktor Lingkungan Yang Berkaitan Dengan Kejadian Leptospirosis di Kabupaten Pati Jawa Tengah. J Kesehat Lingkung Indones 2014;13:51-7.

[11] Ramadani T, Astuti NT. Karakteristik Individu dan Kondisi Lingkungan Pemukiman di Daerah Endemis Leptospirosis di Kota Semarang. Media Litbang Kesehat 2015;25:153-62.

[12] Unggul N, Budiyono, Nurjazuli. Faktor Lingkungan dan Perilaku Kejadian Leptospirosis di Kota Semarang. J Kesehat Masy 2016;4:407-16.

[13] Maniiah G, Raharjo M, Astorina N. Faktor Lingkungan yang Berhubungan dengan Kejadian Leptospirosis di Kota Semarang. J Kesehat Masy 2016;4:792-8.

[14] Minter A, Costa F, Khalil H, Childs J, Diggle P, I.Ko A, et al. Optimal Control of Rat-Borne Leptospirosis in an Urban Environment 2019;7. doi:10.3389/fevo.2019.00209.

[15] Jorge S, Schuch RA, Oliveira NR De, Pouey E, Gomes CK, Oliveira TL, et al. Human and animal leptospirosis in Southern Brazil: A five-year retrospective study. Travel Med Infect Dis 2017. doi:10.1016/j.tmaid.2017.07.010.

[16] Setiyani E. The Presence Of Rat And House Sanitation Associated With Leptospira sp . Bacterial Infection In Rats ( A Cross Sectional Study In Semarang, Central Java Province, Indonesia ) 2018;6008:1-4.

[17] Fajriyah SN, Udiyono A, Saraswati LD. Environmental and Risk Factors of Leptospirosis : A Spatial Analysis in Semarang City E 2017. doi:10.1088/1742-6596/755/1/011001.

[18] Katulistiwa NA, Lestari KS. Analisis kondisi rumah dan keberadaan tikus yang berpengaruh terhadap kejadian leptospirosis di kabupaten klaten 2014:1-13. 